\title{
Corner's Riau Pocket and other phytogeographical provinces in Peninsular Malaysia
}

\author{
R. Kiew ${ }^{1} \&$ L.G. Saw ${ }^{2}$ \\ ${ }^{1}$ Forest Research Institute Malaysia, \\ 52109 Kepong, Selangor, Malaysia \\ ruth@frim.gov.my \\ ${ }^{2}$ Penang Botanic Gardens \\ Jalan Kebun Bunga, 10350 Penang, Malaysia
}

\begin{abstract}
Four phytogeographical provinces have been recognised in Peninsular Malaysia - the Northern Province, the Perak Province, the Continental Intrusion and the Riau Pocket. The Riau Pocket, originally spelt Riouw, was restricted to SE Johor, Singapore, Banka, Riau Islands, SE Sumatra and NW Borneo but later was expanded to cover the entire east coast of Peninsular Malaysia as far north as Kelantan on the premise that this area harboured the Borneo element of the flora. However, based on a combination of a characteristic assemblage of species, a significant number of endemic species, and the absence of species from adjacent areas, the Riau Pocket is reinstated in its original sense. The boundary between the Riau Pocket and the east coast flora appears to be the Sungai Anak Endau. The Northern Province is a distinct province that lies in the northwest of Peninsular Malaysia that experiences a monsoon climate. It harbours a characteristic assemblage of species and has close affinity with the flora of southern Thailand. Based on the distribution of a sample of 969 taxa, the continental element is shown to be a significant part of the Peninsular Malaysian flora (about a fifth of species) but it is not restricted to a particular area. The Continental Intrusion originally defined by Corner is therefore not supported. The Perak Province is also not recognised because the 969-taxon sample demonstrates that it does not harbour a characteristic assemblage of species nor does it have distinct boundaries. In addition, although the 969-taxon sample shows that for the flora in general there are more Sumatra species than Borneo species in Peninsular Malaysia, the Sumatra species are not better represented in Perak, nor are Borneo species better represented on the east coast.
\end{abstract}

Keywords. Borneo, Continental Intrusion, endemism, Johor, Northern Province, Northwest Borneo Province, Perak Province, Riau Pocket, Sumatra, Terengganu

\section{Introduction}

Peninsular Malaysia is the southernmost landmass of continental Asia. Whilst much of continental Asia experiences a monsoon climate with a distinct dry season, Peninsular Malaysia lies for a large part within the equatorial zone, and receives rain throughout the year. This difference in climate has a profound effect on the flora, which Van Steenis (1950) illustrated by mapping the distribution of genera. He found that 200 continental genera do not go further south than the Isthmus of Kra in Peninsular Thailand and conversely 375 Malesian genera do not go further north than this. The 
Isthmus of Kra boundary marks the northern extent of the phytogeographical region of Malesia, which extends as far south and east as New Guinea (Van Steenis, 1950). Ridley (1922) had earlier recognised the difference between the two floras and placed the boundary between the flora that experiences a distinct dry season and the flora that does not as the Sungai Kedah. Later, Whitmore (1984) redefined the boundary as a line running from Kangar in Perlis, Malaysia, to Pattani in Thailand. Van Steenis further divided Malesia into regions with Peninsular Malaysia lying within Sundaland that encompasses the equatorial rainforest floras of Sumatra and Borneo as its core with some species reaching Java and the Philippines.

To date (Wong, 1998), four phytogeographical provinces have been recognised in Peninsular Malaysia: the Northern Province, the Perak Province, the Continental Intrusion and the Riau Pocket based on characteristic assemblages of species. The database of taxa revised by the Flora of Peninsular Malaysia project provides the opportunity to reassess the status of these provinces based on a much larger sample of about a thousand taxa.

\section{Methodology}

With seven volumes of the seed plants of the Flora of Peninsular Malaysia, Series 2 completed, covering 28 families, we examined the distribution patterns of the indigenous taxa revised in these volumes (Kiew et al., 2010, 2011, 2012, 2013, 2015, 2017, 2018) and dipterocarps (Chua et al., 2010). Distribution maps were generated using DIVA-GIS software and were based on examination of specimens in the KEP, SING and in most cases K and L herbaria too. Localities follow those in Hamidah et al. (2011).

This sample included 1006 taxa (species, subspecies and varieties); 969 indigenous taxa and 37 species naturalised in Peninsular Malaysia. Naturalised species were not included in any further analysis in this paper. Of the 969 indigenous taxa examined, 958 were species and another 11 as lower rank taxa. This large database represents only a fraction (about 12\%) of the total seed plant flora (about 8000 species). However, considering it has taken 9 years to produce, it is impractical to wait decades for the Flora to be completed and a complete dataset becomes available for analysis. While recognising that the 969 taxa are a partial dataset, it nevertheless provides the opportunity to make the important move away from defining provinces based on a small number of 'iconic' species.

Based on the distribution pattern of each taxon, we scored their biogeographical affinities based on the criteria defined in Table 1. We further defined their distribution in Peninsular Malaysia, noting if they are endemic to Peninsular Malaysia, restricted in distribution to a particular region in Peninsular Malaysia (e.g. west coast, east coast, south), noting particularly those taxa restricted to Corner's Riau Pocket sensu stricto, the Northern Province and the Perak Province. 
Table 1. Criteria used to define the distribution affinities of the taxa used in the analysis.

\begin{tabular}{ll} 
Biogeography affinity & Criterion \\
\hline Continental & $\begin{array}{l}\text { Distribution from Continental Asia including India and } \\
\text { extending into Peninsular Malaysia, possibly to neighbouring } \\
\text { islands of Sumatra, Borneo and beyond, but not to Australia } \\
\text { and Pacific Islands }\end{array}$ \\
Indo-Malayan & $\begin{array}{l}\text { Distribution from Continental Asia including India, through } \\
\text { Malesia, extending to Australia and the Pacific Islands or } \\
\text { beyond }\end{array}$ \\
Malesian & $\begin{array}{l}\text { Malesian distribution, may extend into S Thailand } \\
\text { Sundaland }\end{array}$ \\
Restricted to Sunda shelf, west of Wallace's line, \\
Pfro-tropics & Widely distributed from Africa and Madagascar to Asia \\
Pan Tropics & Worldwide tropical distribution \\
Australia/Pacific & $\begin{array}{l}\text { Distribution from Australia and Pacific Islands, north through } \\
\text { Malesia to Asa }\end{array}$
\end{tabular}

\section{Phytogeographical elements within Peninsular Malaysia}

Apart from endemic species, the great majority of taxa in the dataset are widespread either Indo-Malayan, or Malesian. Very few species extend north from Australia and Pacific Islands to Peninsular Malaysia (the Australia/Pacific element) or extend from Malesia to Madagascar and tropical Africa (Afro-tropical species) and even fewer are pan-tropical (Table 2).

Based on the distribution of genera of seed plants in Peninsular Malaysia, Keng (1970) showed that the Indo-Malayan element, Continental element and Malesian element each represented about a third of the genera, while the Australia and Pacific Islands made up a small fraction, only 4\% in Keng's analysis but none in our results (Table 2). Chin (1977) from his checklist of 1079 species of the limestone flora, one of the few reliable substantial datasets available, showed that at the species level Malesian species predominate and that Indo-Malayan species outnumber species with Continental distribution. The sample of 969 taxa of indigenous seed plants (about 10\% of the Peninsula's flora) mapped in volumes 1-7 of the Flora of Peninsular Malaysia, Series 2 and the Peninsular Malaysian Red List of dipterocarps also showed the predominance of Malesian taxa but that Continental taxa far outnumber taxa with IndoMalayan distribution. Inevitably there is some bias in the sample due to the families included, e.g. the Convolvulaceae and Cucurbitaceae have a higher representation of 
Table 2. Distribution affinities of Peninsular Malaysian taxa

\begin{tabular}{lllllll}
\hline Elements & Keng & Genera \% & Chin & Species \%o & $\begin{array}{l}\text { Our } \\
\text { results }\end{array}$ & Taxon \% \\
\hline $\begin{array}{l}\text { Afro- and Pan- } \\
\text { tropical }\end{array}$ & - & & 41 & 3.8 & 51 & 5.3 \\
$\begin{array}{l}\text { Indo-Malayan } \\
\text { Continental }\end{array}$ & 451 & 33 & 319 & 29.6 & 89 & 9.2 \\
Malesia & 435 & 32 & 228 & 21 & 200 & 20.6 \\
(endemic) & $(20)$ & & 491 & 45.5 & 629 & 64.91 \\
Australia/Pacific & 53 & 3.9 & 0 & & $(194)$ & \\
\hline Total & 1363 & & 1079 & & 0 & \\
\hline
\end{tabular}

the Pan- and Afro-tropical species and none of the families represent the Australian/ Pacific Islands element. It is from taxa that have a restricted distribution that several phytogeographical elements have been recognised within Peninsular Malaysia (Fig. 1).

\section{Phytogeographical Provinces in Peninsular Malaysia}

Phytogeographical provinces are recognised by a combination of their characteristic assemblage of species, a significant number of endemic species, and the absence of species from adjacent areas. Of the four phytogeographical provinces, the Northern Province lies outside Malesia as defined by Van Steenis (1950).

1. Northern Province (NW Peninsular Malaysia north of Kangar, Perlis, and including the Langkawi Islands) experiences a pronounced dry season for two to three months during December to March and includes many Burmese or Thai species (Saw, 2010). The characteristic forest type is white meranti-gerutu forest. The northern influence is particularly strong for the limestone flora with species composition of the karst hills of Kedah (including Langkawi Islands) and Perlis showing great similarities in species composition with karst limestone in Peninsular Thailand. The Flora of Peninsular Malaysia treats Peninsular Thailand as part of this phytogeographical province as the Northern Province is artificially split by the political boundary. Thus, among the 195 endemic species in the 969-taxon dataset, 25 species were recorded that span this political boundary and also occur in Peninsular Thailand. Among our sample of 969 


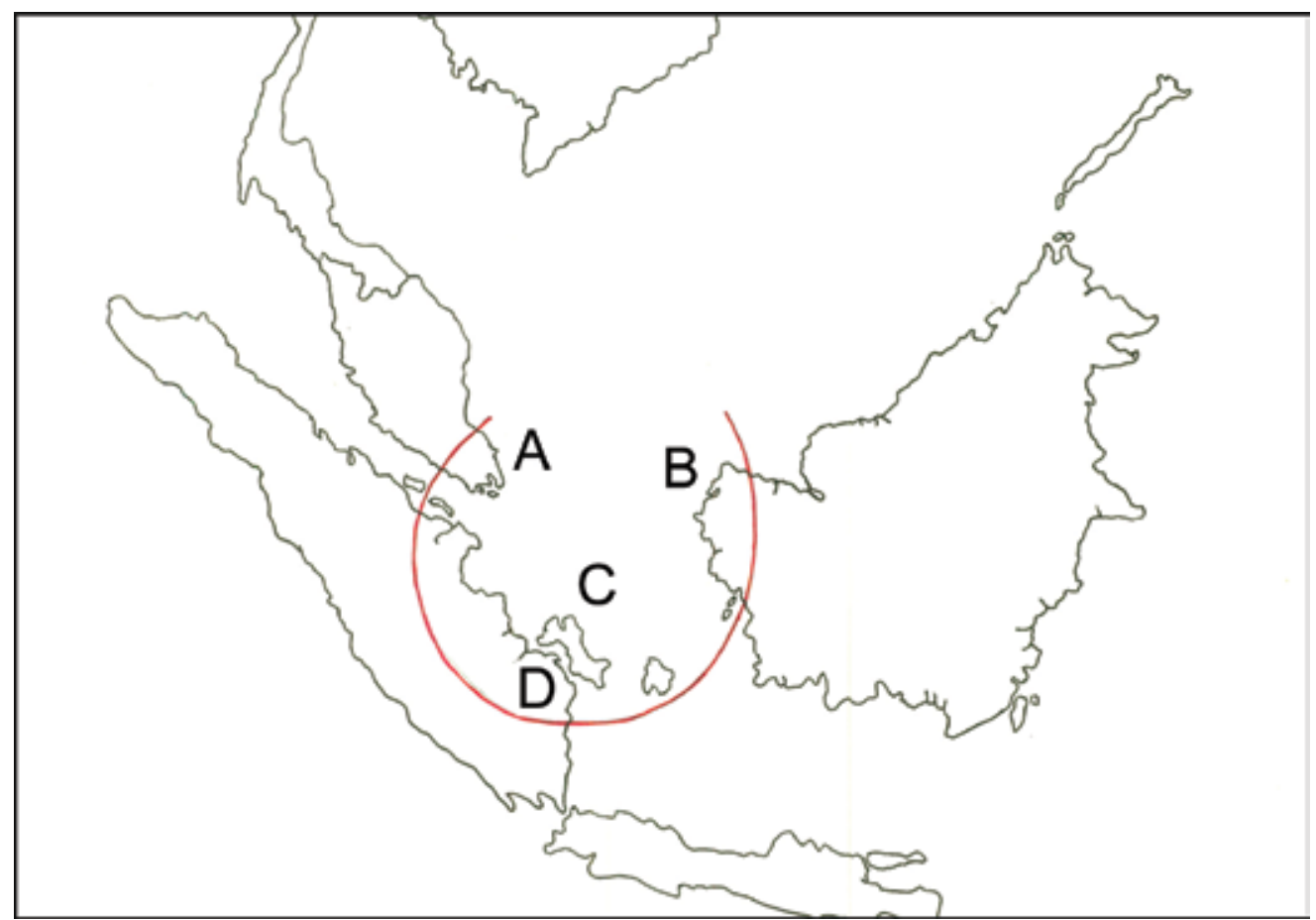

Fig. 1. Corner's Riau Pocket. A. SE Johor and Singapore; B. Western subprovince of Northwest Borneo Province; C. Banka and Riau Islands; D. SE Sumatra. (After Corner, 1978).

taxa, 31 taxa $(3.2 \%)$ were confined to this province. Although contributing relatively few species to the flora, it is nevertheless a distinct province confined by climatic factors and has a precise boundary.

2. The Riau Pocket: Corner (1958) first described and later elaborated (Corner, 1960) his Riau (as Riouw) Pocket sensu stricto to cover SE Johor, Singapore, Banka, Riau Islands, SE Sumatra and NW Borneo (Fig. 1).

Later Ashton (1992) and Wong (1998) greatly enlarged the Riau Pocket sensu lato to take in Wyatt-Smith's Borneo element (Wyatt-Smith, 1963) on the east coast of Peninsular Malaysia extending it from SE Pahang to the Terengganu-Kelantan border. They emphasised shared species with Ashton's Northwest Borneo Province (Ashton, 1992, 1995).

Progress in plant exploration in SE Johor includes two detailed floristic studies of Corner's Riau Pocket sensu stricto, by Corner (Corner, 1978) and by the Malaysian Nature Society Endau Rompin Expedition (Wong et al., 1987a, 1987b; Kiew, 1987). In addition, revisions of Malaysian taxa, for example, in the Tree Flora of Malaya, Tree Flora of Sabah \& Sarawak and Flora of Peninsular Malaysia, and mapping of dipterocarp distribution (Chua et al., 2010; Saw \& Sam, 2000) enable a reassessment of the status of the Riau Pocket sensu stricto as a distinct phytogeographical province, its constituents and boundaries based on a combination of (a) a characteristic 
assemblage of species, (b) the presence of a significant number of endemic species, and (c) absence of species from the adjacent areas; or whether, as Ashton (1992) and Wong (1998) suggested, the Riau Pocket sensu lato extends north up the east coast to the Terengganu-Kelantan border.

\section{Reassessment of the Boundaries of Corner's Riau Pocket sensu stricto}

The northern limit of the Riau Pocket sensu stricto in Peninsular Malaysia appears to be the Sungai Anak Endau, Pahang. Thus, the Menchali Forest Reserve north of Sungai Rompin in Pahang, is outside the Riau Pocket, while Gunung Arong, Johor, lies within it.

The Riau Pocket includes areas of peat swamp forests, a plant community that in Peninsular Malaysia has a restricted distribution and is mostly found in SE Johor, and less extensively in Pahang north of the Rompin River and near Kuantan, and on the west coast there is a small area in the Telok Forest Reserve, Selangor, and Hutan Melintang, Perak (Saw, 2010). Many peat swamp forest species characteristic of the Riau Pocket sensu stricto in Peninsular Malaysia are, however, not found outside SE Johor.

\section{Characteristic assemblage of Riau Pocket species}

These are species that in Peninsular Malaysia are restricted to SE Johor but whose distribution extends into areas within Singapore, Banka, the Riau Islands, Sumatra or Borneo (Corner, 1978), such as Barringtonia reticulata (Blume) Miq., Cotylelobium melanoxylon (Hook.f.) Pierre, Dracaena cantleyi Baker, Ficus ruginervia Corner, Shorea inappendiculata Burck, S. johorensis Foxw. and S. peltata Symington; and Vatica ridleyana Brandis restricted to Johor, Singapore and Sumatra; and Ficus uncinulata Corner, Mangifera paludosa Kosterm., Pandanus epiphyticus Martelli, $P$. rostratus Martelli, Rothmannia kuchingensis (W.W.Sm.) K.M.Wong, and Sebastiana borneensis Pax \& K.Hoffm. to Johor and Borneo.

Riau Pocket sensu stricto endemic species

Intensive exploration of the area has revealed many endemic species (Corner, 1978; Wong et al., 1987a, 1987b; Kiew \& Wong, 1988; Kiew, 1987). This list is no doubt incomplete as new species continue to be discovered: Aidia lancifolia K.M.Wong, Alseodaphne corneri Kosterm., Barringtonia corneri Kiew \& K.M.Wong, Calamus endauensis J.Dransf., C. flabellatus Becc., Codonoboea craspedodroma Kiew, C. falcata Kiew, C. nivea Kiew, Cratoxylon glaucum Korth., Dillenia albiflos (Ridl.) Hoogland, Ficus ruginervia Corner, Hoya endauensis Kiew, Kopsia deverrei L.Allorge, Licuala kiahii Furtado, L. kamarudinii Saw, L. lanuginosa Ridl., L. longicalycata Furtado, L. thoana Saw \& J.Dransf., L. whitmorei Saw, Loxocarpus tunkui Kiew, Morinda hispida K.M.Wong, Pandanus echinodermops Holttum \& H.St.John, Phyllagathis stolonifera Kiew, Phyllanthus watsonii Airy Shaw, Pinanga palustris Kiew, Salacca graciliflora Mogea, S. minuta Mogea, Schoutenia furfuracea Kochummen, S. leprosula Saw, Trigonostemon rufescens Jabl. and Tristaniopsis pontianensis (M.R.Hend.) Peter G.Wilson \& J.T.Waterh. 
Absence in the Riau Pocket sensu stricto of species from the adjacent areas

The northern limit of the Riau Pocket sensu stricto appears to be the Sungai Anak Endau as exemplified by the distribution of Hopea kerangasensis P.S.Ashton and Vatica lowii King that reach their southernmost limit there. Widespread species, like Anisoptera marginata Korth., Baeckea frutescens L., Sandoricum beccarianum Baill., Shorea materialis Ridl. and S. playtcarpa F.Heim., or species common east of the Main Range like Cotylelobium lanceolatum Craib and Dipterocarpus oblongifolius Blume, noticeably shun the Riau Pocket.

\section{Wyatt-Smith's Borneo element}

Wyatt-Smith (1963) noted that "in the south east there is a strong Bornean element which extends as far north as the border between Kelantan and Terengganu". Ashton (1992, 1995) has demonstrated that in Borneo, species shared between Peninsular Malaysia and Borneo occur within his Northwest Borneo Province that lies north of a line from Pontianak to Sipitang. He further divided the Northwest Borneo Province into two: the eastern subprovince extending from the Crocker Range, Sabah, to the Lupar River, Sarawak; and the western subprovince extending from the Lupar Valley, Sarawak, to the Kapuas Lakes, Kalimantan (Fig. 2). It is this latter subprovince that Corner (1978) included in the Riau Pocket sensu stricto

Distribution of dipterocarp species has played a dominant role in the perception of the Riau Pocket sensu lato extending to cover the east coast as far as south Kelantan. However, our sample of 28 families shows that the number of taxa in common between Peninsular Malaysia and Borneo alone is small compared with either the number of species in common between Peninsular Malaysia, Borneo and Sumatra, and between Peninsular Malaysia and Sumatra (see Perak Province below). Among Borneo species common to Peninsular Malaysia, there is also a distinction between the Riau Pocket sensu stricto species (eight species) and east coast species that do not extend into SE Johor (seven species, including Cotylelobium lanceolatum Craib, Dipterocarpus sarawakensis Slooten, Hopea coriacea Burck, H. nutans Ridl., Quercus nivea King, Shorea atrinervosa Symington and S. materialis Ridl.) lending further support to the distinction between the flora of Corner's Riau Pocket sensu stricto and that of the east coast flora north of the Sungai Anak Endau, Pahang. The bulk of the east coast flora comprises widespread species and includes Indo-Malayan, Continental, and Malesian elements. Noticeably absent, however, are species of the Peninsular Malaysian Northern Province and of the Riau Pocket sensu stricto.

The characteristic species assemblages on the east coast are in a large part due to edaphic factors. In comparison with the west coast, beach vegetation and coastal forest are well-developed and extensive; coastal hill forest grows on sandstone substrates, and heath forest on sandy, acidic, nutrient-poor soils (Saw, 2010). The montane forests of the Terengganu Hills also appear to differ significantly from those of the Main Range on the west coast with a low representation of Ericaceae and high representation of the Australian element, such as Machaerina maingayi (C.B.Clarke ex Ridl.) T.Koyama, Styphelia malayana (Jack) Spreng. and Xyris bancana Miq. (Ummul-Nazrah et al., 2011). The east coast flora is still relatively poorly known botanically. This is illustrated 
by the tally by $\mathrm{Ng}$ et al. (1990) of endemic tree species where Terengganu, with 18 species, ranks fourth after Perak (103 species) Pahang (76) and Selangor (21). As nontree genera are revised, the number of new species is increasing dramatically with many endemic to Terengganu. For example, of the nine Terengganu Thottea species, five are endemic (Yao, 2015); nine of the 20 Terengganu Codonoboea species are endemic (Kiew \& Lim, 2019) and as are 16 palm species (Saw, 1997), Calamus pycnocarpus (Furtado) J.Dransf., Iguanura humilis (Kiew) C.K.Lim, I. mirabilis C.K.Lim, Pinanga cleistantha J.Dransf., P. sarmentosa Saw and 11 Licuala species - L. ahlidurii Saw, L. bayana Saw, L. corneri Furtado, L. fractiflexa Saw, L. kemamanensis Furtado, L. khoonmengii Saw, L. moyseyi Furtado, L. ruthiae Saw, L. sallehana Saw var. sallehana \& var. incisifolia Saw, L. tenuissima Saw and L. terengganuensis Saw.

3. The Continental Intrusion that Corner (1960) drew attention to and described as penetrating into central Peninsular Malaysia as far south as central Pahang (Fig. 1) was exemplified by the distribution of Koompassia excelsa (Becc.) Taub. that is common in the north but extends only as far south as Mentakab, Pahang. Another example is the flora of Fraser's Hill, Pahang, where 14 continental species reach their southernmost limit in the Peninsula (Kiew, 1998).

Emphasis on the boundaries of the Malesian flora (Van Steenis, 1950) somewhat overshadowed the importance of the Continental element in Peninsular Malaysia until Keng (1970) showed its importance in contributing about a third of the genera. Our sample shows it contributes at least a fifth of the taxa $(20.6 \%)$. This is not unexpected due to Peninsular Malaysia's land connection to the Asian Continent. With the sample of 969 taxa we are able to test whether Corner's Continental Intrusion warrants being regarded a province or whether it was based on a few conspicuous species.

Among the 286 continental taxa (Table 1), 31 are confined to the Northern Province and 65 are found only as far south as Pahang and Selangor, i.e. within Corner's area of the Continental Intrusion, indicating that the great majority $(76 \%)$ in fact are distributed throughout Peninsular Malaysia. Our sample also illustrates that, as might be expected, the continental element weakens toward the south and west: of the sample, 736 taxa (76\%) are limited to the west of the Wallace's Line and only 233 taxa $(24 \%)$ cross it.

In conclusion, while Corner was correct in drawing attention to the importance of the Continental element of the flora, the distributions of a larger sample of species shows that the great majority of Continental taxa are distributed beyond the area of the Continental Intrusion outlined by Corner with many reaching as far south as Wallace's Line. Thus, the concept of the Continental Intrusion is not supported as a distinct province.

4. The Perak Province was described by Ashton (1992) to encompass (a) the Manjung District including Dindings and Segari Melintang Forest Reserve, where Dipterocarpus lowii Hook.f. and Shorea macrantha Brandis that he considered were "outliers of the Riau Pocket" grow, and (b) Gunung Bubu and the Keledang Siong Forest Reserve with species like Dipterocarpus perakensis P.S.Ashton (also in Penang), Shorea lumutensis 


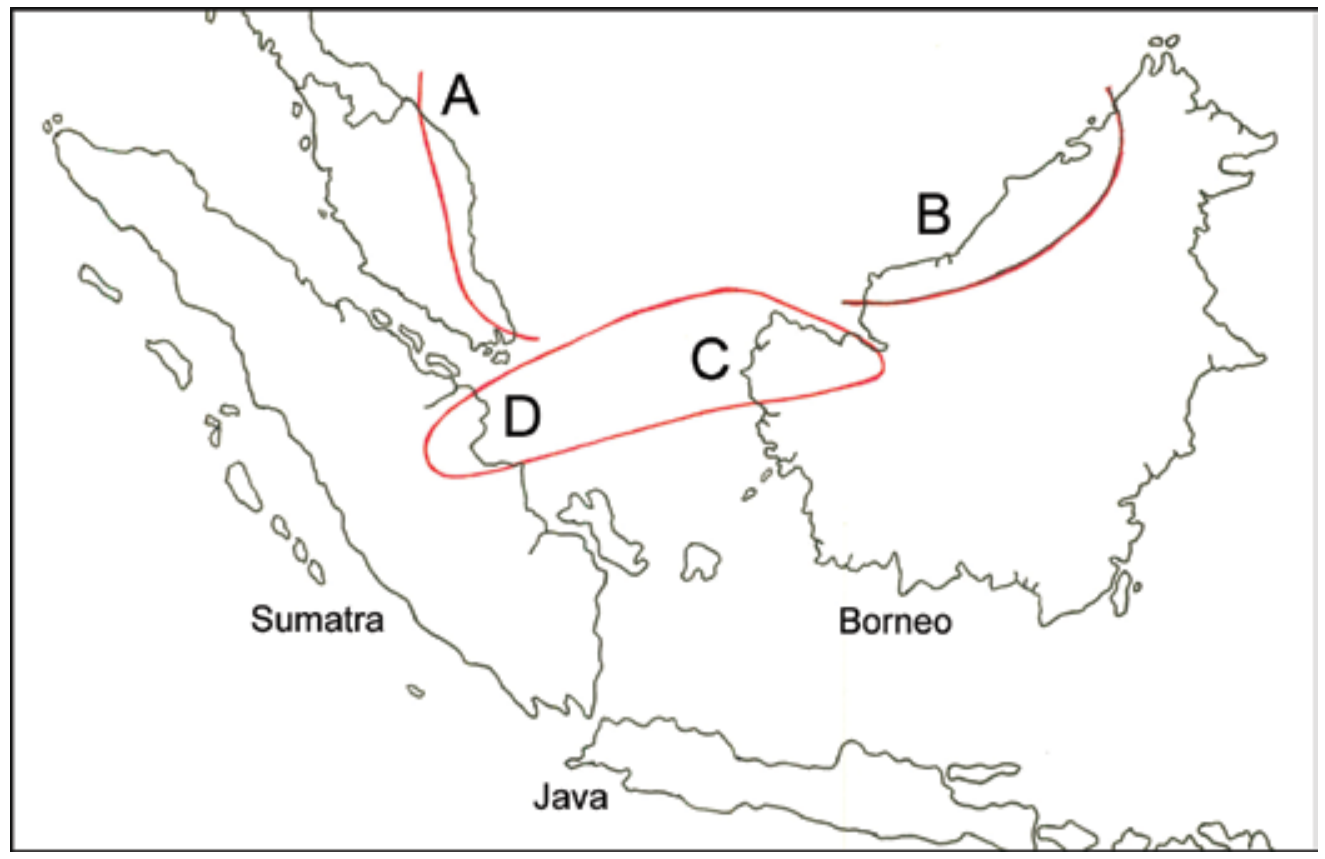

Fig. 2. Ashton's Riau Pocket. A. East coast of Peninsular Malaysia (Kelantan, Terengganu, east Pahang, SE Johor); B. Northwest Borneo Province (eastern subprovince); C. Northwest Borneo Province (western subprovince); D. Bangka and adjacent Sumatra. (After Ashton, 1992).

Symington and the relict Maingaya malayana Oliv. (now also known from Penang, Kedah and Negeri Sembilan) occur, as well as (c) a significant Sumatran connection (Vatica lowii King, V. perakensis King and Parashorea globosa Symington). However, most of these species are widespread and found outside Ashton's Perak Province, except for Parashorea globosa (in Sumatra and in Peninsular Malaysia where it is restricted to the Keledang Siong Forest Reserve) and Shorea lumutensis (endemic in Peninsular Malaysia and restricted to coastal hill dipterocarp forest).

Wong (1998) extended the area of the Perak Province to cover most of the west coast, not only Perak but also adjacent areas in Kedah and Selangor. It is not then surprising that it is particularly biodiverse. For example, $\mathrm{Ng}$ et al. (1990) recorded 103 endemic tree species from Perak as compared with an average of 27 (range 9-76) species for the other states. Two reasons have been suggested for its high biodiversity: the inclusion of Sumatran species; and the few species characteristic of heath or swamp forest in the Dindings area (Ashton, 1992). However, Wong (1998) has pointed out the Sumatran element is weak and that in any case Sumatran species are found scattered throughout the lowlands.

Among our 969-taxon sample, only 18 non-endemic species are restricted to Ashton's concept of the Perak Province, hardly sufficient to warrant recognition as a province.

In addition, the assertion that Sumatran species are particularly well represented 
is not supported. Of the 357 Malesian taxa (excluding endemic species), the great majority (210 species) are widespread in core Sundaland (Sumatra, Peninsular Malaysia and Borneo) compared with 82 in common between Sumatra and Peninsular Malaysia, and 65 in Peninsular Malaysia and Borneo. However, of the 82 'Sumatran' species only 3 species are confined to the Perak Province supporting Wong's view that the Sumatra influence there is weak.

The exceptionally high biodiversity in Perak as compared with other states may in part be attributed to botanical exploration. Perak was intensely botanised in the 1880 s by H. Kunstler (also known as Dr King's collector) working for George King of the Calcutta Herbarium, India, and by Father Benedetto Scortechini, who was employed by Hugh Low, Governor of Perak. Many of the areas where they collected no longer have primary vegetation, such as the Gopeng area which was being opened up for tin-mining in Kunstler's time as was subsequently much of the Kinta Valley, and since that time large areas of lowland forest were converted to plantations. In other states, such as Johor and Pahang, large areas were logged and converted into oil palm plantations in the 1970s and 1980s without any intensive botanical collection meaning that the extent of their biodiversity will never be known.

Before the Flora of Peninsular Malaysia project, which now provides accurate distribution maps and a large dataset, provinces were based on a few charismatic species, such as Maingaya malayana Oliv. From our 969-taxon sample, it is clear that Ashton's and Wong's Perak Province cannot be upheld as a province because it does not have a discrete boundary within which a characteristic assemblage of species is restricted, while other species in adjacent areas are excluded. Moreover, the Sumatra link is shown not to be specific to this area but is generally more widespread over the entire Peninsula. However, Ashton (1992) was correct in drawing attention to the Manjung district (his Dindings area with the Segari Melintang Forest Reserve) that is of great conservation importance (Davis, 1995). Here within a small area are several edaphic forest types that are not widespread in Peninsular Malaysia, coastal dipterocarp forest, heath forest and freshwater swamp forest, and where Critically Endangered species such as Dipterocarpus semivestitus Slooten and Shorea lumutensis Symington occur.

\section{Conclusion}

From the distribution patterns of species with restricted distributions, two distinct phytogeographical provinces are recognised in Peninsular Malaysia (Fig. 3): the Northern Province and Corner's Riau Pocket. The Riau Pocket in Corner's original sense in Peninsular Malaysia is a discrete province with a characteristic assemblage of species, many endemic species, and is clearly separated from adjacent areas by the absence of some species. It includes species with a Sumatran-Borneo-Peninsular Malaysian distribution that do not extend further north of the Sungai Anak Endau, Pahang. It is distinct from the east coast flora that extends from roughly north from the Sungai Anak Endau, Pahang, to the Terengganu-Kelantan border.

The 969-taxon sample also provides evidence that while the Continental 


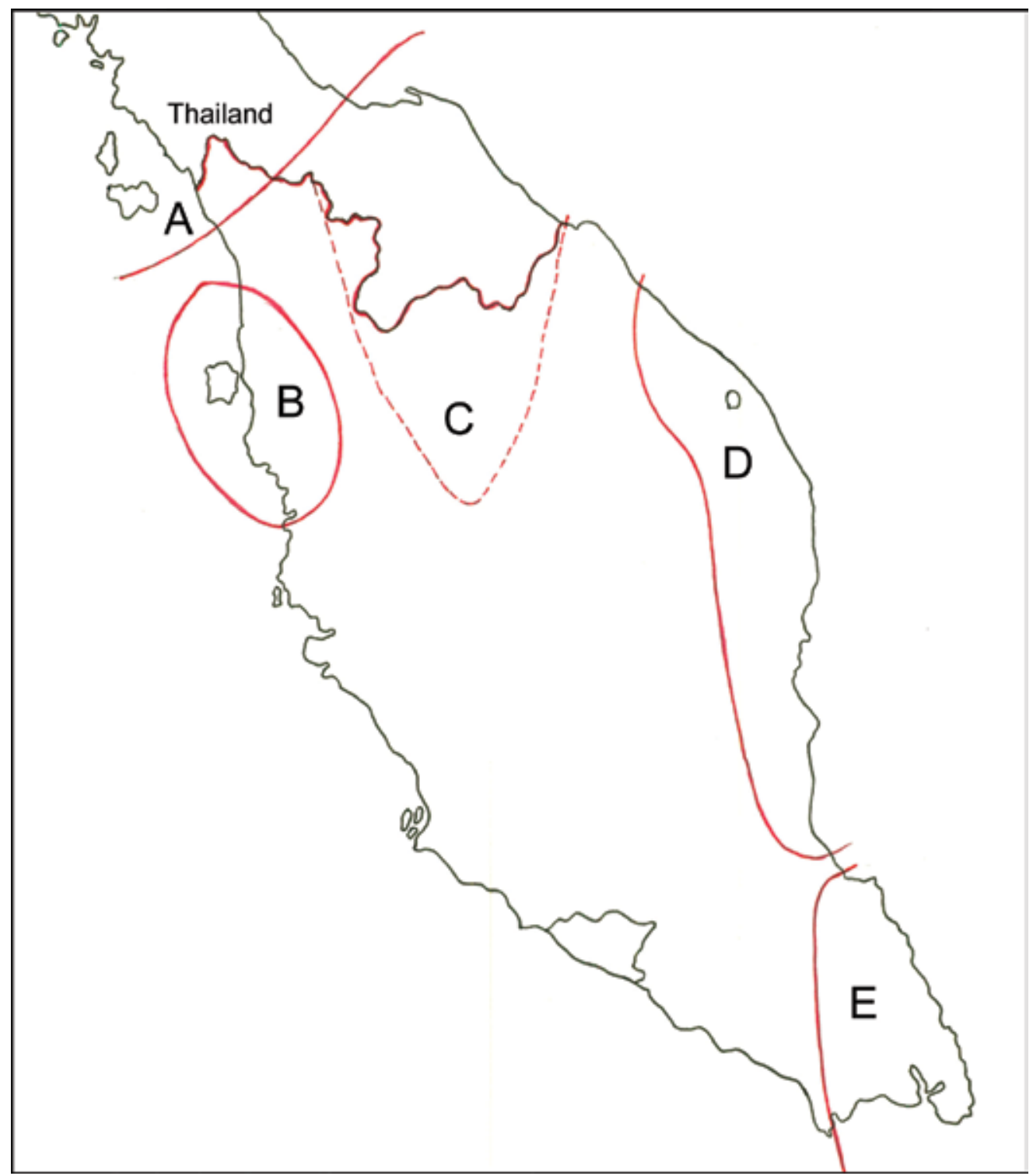

Fig. 3. Phytogeographical Provinces described from Peninsular Malaysia. A. Northern Province; B. Perak Province; C. Continental Intrusion; D \& E. Ashton's Riau Pocket; E. Corner's Riau Pocket.

element contributes a significant proportion (about $20 \%$ of taxa) to the flora, only a small fraction of them are restricted within the area of the Continental Intrusion suggested by Corner (1960). The great majority of species in the dataset $(76 \%)$ are much more widely distributed. This means that the Continental Intrusion cannot be upheld as a distinct province.

The Perak Province (Ashton, 1992) was characterised by very few species, many 
of which have since proved to be more widespread. To expand the area to accommodate them, as was suggested by Wong (1998), results in the Perak Province encompassing most of the west coast. Our 969-taxon sample does not provide any support for it being a distinct province. In addition, as Wong noted, Sumatra species are not particularly concentrated within this area but are widespread throughout the Peninsula. Similarly, our dataset shows that Borneo species are not particularly concentrated on the east coast and our sample shows that Sumatra species outnumber those from Borneo.

Data from the first seven volumes of the Flora of Peninsula Malaysia also indicate regions and areas that would repay detailed investigation and would give insights into their phytogeographical affinities. The east coast flora remains relatively poorly known botanically compared with the west coast. More intensive botanical collecting is required to obtain a basic understanding of its flora and the relative importance of its phytogeographic elements. Present indications are that it harbours many endemic species. Of particular interest too are the mountain floras. Conspicuous species point to differences between the Bintang Range, the Main Range, Gunung Tahan and the Terengganu Hills, but whether these differences are reflected on a broader scale is not known. In addition, some areas remain conspicuously under-collected such as Perlis (non-limestone localities), Kelantan, the eastern side of Main Range, and the Terengganu Hills.

Ideally the way forward is undoubtedly through analysis of DNA sequence data that can identify ancestral areas and date dispersal events, like the study by Thomas et al. (2012) for Begonia. However, it is unrealistic to hope that such studies, though fascinating, will be able to cover more than a minuscule number of taxa compared to the vast biodiversity of the flora. In the absence of such studies, accurately mapped distributions, such as those generated by modern Floras, are an advance on recognising provinces based on relatively few salient species.

DEDICATION AND ACKNOWLEDGEMENTS. For David J. Mabberley for his staunch support of tropical botany and the indispensable Mabberley's plant-book. E.J.H. Corner's inspirational lectures introduced the first author to the biodiversity of tropical rain forest in Malaysia.

The first author has also benefited from discussions the P.S. Ashton, T.C. Whitmore, C.G.G.J. van Steenis and K.M. Wong. The databasing was made possible through BRAHMS (Botanical Research and Herbarium Management System) under the stewardship of Dr Denis Filer. Universiti Pertanian Malaysia (to the first author) and Forest Research Institute Malaysia provided opportunities to carry out field work throughout Peninsular Malaysia. We are deeply grateful to the unfailing support given by the many field staff who accompanied us on botanical collecting trips. We are indebted to the Ministry of Water, Land and Natural Resources (KATS) of Malaysia under the 11th Malaysia Plan (SPPII No. P23085100018003) who fund the Flora of Peninsular Malaysia Project. 


\section{References}

Ashton, P.S. (1992). Plant conservation in the Malaysian region. In: Yap, S.K. \& Lee, S.W. (eds) In harmony with nature: Proceedings of the International Conference of Tropical Biodiversity, pp. 86-93. Kuala Lumpur: Malaysian Nature Society.

Ashton, P.S. (1995). Biogeography and Ecology. In: Soepadmo, E. \& Wong, K.M. (eds) Tree flora of Sabah \& Sarawak, vol. 1, pp. xxliii-xlix. Malaysia: Sabah Forestry Department, Forest Research Institute Malaysia and Sarawak Forestry Department.

Chin, S.C. (1977). The limestone flora of Malaya I. Gard. Bull. Singapore 30: 165-219.

Chua, L.S.L., Suhaida, M., Hamidah, M. \& Saw, L.G. (2010). Malaysia Red List. Peninsular Malaysian Dipterocarpaceae, Research Pamphlet No. 129. Malaysia: Forest Research Institute Malaysia.

Corner, E.J.H. (1958). An introduction to the distribution of Ficus. Reinwardtia 4: 15-45.

Corner, E.J.H. (1960). The Malayan flora. In: Purchon, R.D. (ed.) Proceedings Centenary and Bicentenary Congress Biology, Singapore, pp. 21-24. Singapore: University of Malaya Press.

Corner, E.J.H. (1978). The freshwater swamp-forest of South Johore and Singapore. Gard. Bull. Singapore, Suppl. 1: 1-266.

Davis, S.D. (1995). Regional overview: South East Asia (Malesia). In: Davis, S.D., Heywood, V.H. \& Hamilton, A.C. (eds) Centres of plant diversity. Vol. 2. Asia, Australasia and the Pacific, pp. 229-299. Cambridge, U.K.: IUCN Publications Unit.

Hamidah, M., Chua, L.S.L., Suhaida, M., Yong, W.S.Y. \& Kiew, R. (2011). Botanical gazetteer for Peninsular Malaysia, Research Pamphlet No. 131. Kepong: Forest Research Institute Malaysia.

Keng, H. (1970). Size and affinities of the flora of the Malay Peninsula. J. Trop. Geogr. 31: 43-56.

Kiew, R. (1987). The herbaceous flora of Ulu Endau, Johore-Pahang, Malaysia including taxonomic notes and descriptions of new species. Malayan Nat. J. 41: 201-234.

Kiew, R. (1998). The seed plant flora of Fraser's Hill, Peninsular Malaysia, with special reference to its conservation status, Research Pamphlet No. 121. Kuala Lumpur: Forest Research Institute Malaysia.

Kiew, R., Chung, R.C.K., Saw, L.G., Soepadmo, E. \& Boyce, P.C. (2010). Flora of Peninsular Malaysia, ser. 2, vol. 1. Kepong: Forest Research Institute Malaysia.

Kiew, R., Chung, R.C.K., Saw, L.G., Soepadmo, E. \& Boyce, P.C. (2011). Flora of Peninsular Malaysia, ser. 2, vol. 2. Kepong: Forest Research Institute Malaysia.

Kiew, R., Chung, R.C.K., Saw, L.G. \& Soepadmo, E. (2012). Flora of Peninsular Malaysia, ser. 2, vol. 3. Kepong: Forest Research Institute Malaysia.

Kiew, R., Chung, R.C.K., Saw, L.G. \& Soepadmo, E. (2013). Flora of Peninsular Malaysia, ser. 2, vol. 4. Kepong: Forest Research Institute Malaysia.

Kiew, R., Chung, R.C.K., Saw, L.G. \& Soepadmo, E. (2015). Flora of Peninsular Malaysia, ser. 2, vol. 5. Kepong: Forest Research Institute Malaysia.

Kiew, R., Chung, R.C.K., Saw, L.G. \& Soepadmo, E. (2017). Flora of Peninsular Malaysia, ser. 2, vol. 6. Kepong: Forest Research Institute Malaysia.

Kiew, R., Chung, R.C.K., Saw, L.G. \& Soepadmo, E. (2018). Flora of Peninsular Malaysia, ser. 2, vol. 7. Kepong: Forest Research Institute Malaysia.

Kiew, R. \& Lim, C.L. (2019). Codonoboea (Gesneriaceae) in Terengganu, Peninsular Malaysia, including three new species. Phytokeys.

Kiew, R. \& Wong, K.M. (1988). Barringtonia corneri (Lecythidaceae), a remarkable new litter-trapping species from Johore, Malaysia. Malayan Nat. J. 41: 457-459.

Ng, F.S.P., Low, C.M. \& Mat Azri Ngah Sanah (1990). Endemic trees of the Malay Peninsula, FRIM Research Pamphlet No. 106. Kuala Lumpur: Forest Research Institute Malaysia.

Ridley, H. N. (1922). Introduction. In: Ridley, H.N. Flora of Malay Peninsula, vol. 1, pp. ixxx. London: Reeve \& Co. 
Saw, L.G. (1997). A revision of Licuala (Palmae) in Peninsular Malaysia. Sandakania. 10: $1-95$.

Saw, L.G. (2010). Vegetation of Peninsular Malaysia. In: Kiew, R., Chung, R.C.K., Saw, L.G., Soepardmo, E. \& Boyce, P.C. (eds) Flora of Peninsular Malaysia, ser. 2, vol. 1, pp. 21-45. Kepong: Forest Research Institute Malaysia.

Saw, L.G. \& Sam Y.Y. (2000). Conservation of Dipterocarpaceae in Peninsular Malaysia. $J$. Trop. Forest Sci. 12: 593-615.

Thomas, D.C., Hughes, M., Phutthai, T., Ardi, W.H., Rajbhandary, S., Rubite, R., Twyford, A.D. \& Richardson, J.E. (2012). West to east dispersal and subsequent rapid diversification of the mega-diverse genus Begonia (Begoniaceae) in the Malesian archipelago. $J$. Biogeogr. 39: 98-113.

Ummul-Nazrah, A.R., Rafidah, A.R., Kiew, R. \& Imin, K. (2011). The botany of Gunung Padang, Terengganu, Malaysia. Malayan Nat. J. 63: 625-660.

Van Steenis, C.G.G.J. (1950). The delimitation of Malaysia and its main plant geographic divisions. Flora Malesiana, ser. 1, vol. 1, pp. lxx-lxxv. Jakarta: Noordhoff-Kolff N.V.

Whitmore, T.C. (1984). Tropical rain forests of the Far East. Oxford: Clarendon Press.

Wong, K.M. (1998). Patterns of plant endemism and rarity in Borneo and the Malay Peninsula. In: Peng, C.-I. \& Lowry II, P.P. (eds) Rare, threatened and endangered floras of Asia and the Pacific Rim, Acad. Sinica Monograph Ser. No 16, pp. 139-169. Taipei: Institute of Botany, Academica Sinica.

Wong, K.M., Saw, L.G. \& Kochummen, K.M. (1987a). A survey of the forests of the EndauRompin area, Peninsular Malaysia: principal forest types and floristic notes. Malayan Nat. J. 41: 125-144.

Wong, K.M., Saw, L.G. \& Kochummen, K.M. (1987b). Some new and interesting plant species from Ulu Endau, Johore, Malaysia. Malayan Nat. J. 41: 267-273.

Wyatt-Smith, J. (1963). Manual of Malayan silviculture for inland forests, 2 vols, Malayan Forest Records No. 23. Kuala Lumpur: Forest Research Institute.

Yao, T.L. (2015). Aristolochiaceae. In: Kiew, R., Chung, R.C.K., Saw, L.G. \& Soepadmo, E. (eds) Flora of Peninsular Malaysia, ser. 2, vol. 5, pp. 5-46. Kepong: Forest Research Institute Malaysia. 